\title{
Drying methods for municipal solid waste quality improvement in the developed and developing countries: A review
}

\author{
Maw Maw Tun ${ }^{1,2^{\dagger}}$, Dagmar Juchelková ${ }^{1}$ \\ ${ }^{1}$ Department of Energy Engineering, VŠB-Technical University of Ostrava, 17. Listopadu 15, Ostrava-Poruba, 70833, Czech Republic \\ ${ }^{2}$ Department of Energy Engineering, Czech Technical University, Zikova 1903/4, 166 36, Prague, Czech Republic
}

\begin{abstract}
Nowadays, drying methods for municipal solid waste quality improvement have been adopted in the developed and developing countries to valorize wastes for a renewable energy source, reduce dependency on fossil fuel and keep safer disposal at landfills. Among them, biodrying, biostabilization, thermal drying and solar drying are the most common. Drying of municipal solid waste could offer several environmental and economic benefits. Therefore, this review highlighted the drying methods for municipal solid waste quality improvement around the world and compared them based on the reduction of moisture, weight and volume of municipal solid wastes against drying temperature and time by using statistical analysis. It was observed that the drying temperature of different drying methods accounted for $115 \pm 40^{\circ} \mathrm{C}$ for thermal drying, $59 \pm 37^{\circ} \mathrm{C}$ for solar drying, $55 \pm 15^{\circ} \mathrm{C}$ for biodrying and $58 \pm 11^{\circ} \mathrm{C}$ for biostabilization. Among the drying methods, thermal drying provided the shortest drying time. The moisture reduction, weight reduction, volume reduction and heating value increase of municipal solid waste could vary with drying temperature and time. Finally, the benefits and drawbacks of different drying methods were specified, and recommendations were made for the future efficient drying.
\end{abstract}

Keywords: Drying, Drying methods, Municipal solid waste, Waste fuel, Waste quality

\section{Introduction}

The amount of municipal solid waste (MSW) in the cities around the world might reach 2.2 billion tons per year by 2025 [1]. The World Bank 2012 Report [1] showed that waste generation rates in developing countries would double in the coming two decades. The MSW in these countries was mainly composed of organic waste that accounted for 50-65\%. Fig. 1 shows the comparison of waste composition around the world. Waste composition could vary with the consumption patterns, living standards and the economic development of the countries. High-income countries had the higher percentages of paper with $24 \%$ of the total than those of the other countries in 2015. Meanwhile, low-income countries had the higher composition of organic wastes, with 53\%. Tchobanoglous and Kreith [2] state that the typical compositions of MSW are 50.89\% combustibles, $27.45 \%$ moisture and $21.57 \%$ non-combustibles. However, since the MSW composition of the developing countries majorly constitutes organic fraction with over $50 \%$ of the total, the moisture content

This is an Open Access article distributed under the terms of the Creative Commons Attribution Non-Commercial License (http://creativecommons.org/licenses/by-nc/3.0/) which permits unrestricted non-commercial use, distribution, and reproduction in any medium, provided the original work is properly cited.

Copyright (C) 2019 Korean Society of Environmental Engineers of the MSW in these countries could be higher than $27.45 \%$. Based on the physical composition analysis on waste composition in 2015, it was observed that the composition of MSW in developing countries including low-income and lower-middle income countries might be in the range of approximately $40-41 \%$ moisture, $28-35 \%$ combustibles and $25-31 \%$ non-combustibles.

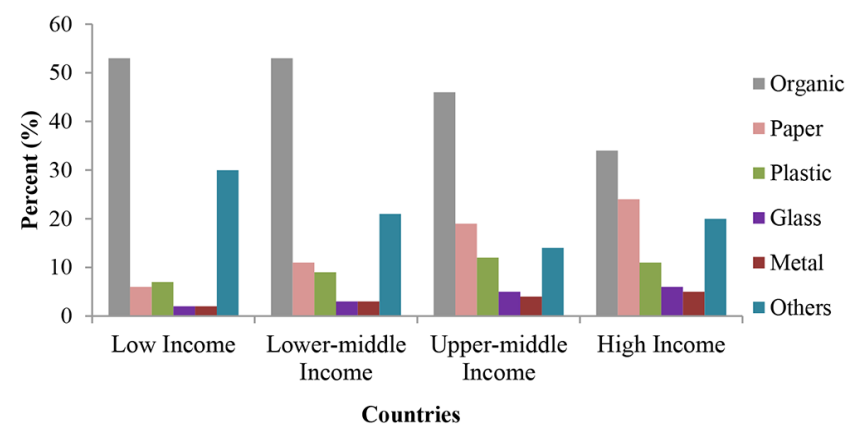

Fig. 1. Comparison of waste composition around the world (2015) [3].
${ }^{\dagger}$ Corresponding author
Email: maw.maw.tun.st@vsb.cz
Tel: $+420-773287487$

ORCID: 0000-0002-6243-3982 
Unlike the developed countries, a waste-to-energy option by thermal waste treatment such as incineration is not appropriate in the developing countries due to the higher organic fractions in their MSW composition [4, 5]. This high moisture content of MSW could lower the recovery of recoverable materials, cause the operational instability and low overall efficiency of the plant and increase the operating cost of combustion [4-6]. Due to the high moisture content of the MSW, low budget for the MSW management and costly waste-to-energy technologies, the major waste disposal methods have commonly become open dumping and landfilling in the developing countries [1, 7-10]. Therefore, waste disposal at open dumpsites and landfills without any control have had negative impacts on the environment and public health in these countries. The environmental issues have been majorly caused by the greenhouse gas (GHG) emissions that are generated from anaerobic digestion of organic wastes to the atmosphere $[11,12]$ and leachate from landfills into the ground water and rivers [13-15]. Meanwhile, the impacts of public health have been significantly caused by the hygienic issues and pollution of air, water and soil.

Waste management is a must for conservation of natural resources as well as for protecting the environment in order to approach sustainable development [16]. Booming economy, growing population, urbanization and industrialization accelerate MSW generation rates [17]. As a result, most of the countries with scarce land areas reach their available capacities of the landfills, hence, encountering higher cost of safe waste disposal and difficulty of locating new disposal sites [16, 18, 19]. Thus, a sustainable approach to MSW management could be taken by utilizing the waste resource effectively to meet human needs and minimize the land use of waste disposal with the sustainability of natural systems and the environment [16].

Nowadays, waste-to-energy has become a type of renewable energy utilization that can provide environmental and economic benefits in the world [20]. When incinerated, not only energy can be benefited from waste, but also waste can be reduced by $80-85 \%$ by weight and by $95-96 \%$ by volume [21]. Hence, the energy-oriented conversion technologies have become a potential to produce the refuse-derived fuel (RDF) from wastes and reduce the bulk volume of the wastes [22]. Perazzini et al. [23] suggest that the proper treatment of organic or inorganic solid wastes such as biodrying is necessary for economic and environmental interests to obtain added-value by-product through resource recovery, energy recovery and reuse. Therefore, the optimization of MSW quality by drying could offer the numerous benefits, including the easier recovery of recoverable materials [23, 24], easier storage for the future, easier transportation and reduction of disposal costs [16, 25, 26], improvement of heating values of waste fuel [24, 27-33] for the efficiency improvement of thermal waste treatment process [6], less dependency on fossil fuels, reduction of waste odor by slowing down the deterioration of the waste [6, 33], reduction of environmental impacts from open dumpsites and landfills [6, 12-14, 31, 34], and mitigation of global warming $[6,35]$.

Most recent studies [6, 16, 23, 24, 27, 31, 36-48] have majorly focused on biostabilization, biodrying methods, solar drying and thermal drying for the pretreatment of high organic concentration of solid wastes. Moreover, numerous studies [4, 22-24, 27-29, 31-34, 36-49] have also investigated the process, performance efficiency and economic feasibility of different drying methods for the quality improvement of solid wastes coming from industrial sector, municipal sector and agricultural sector. However, as far as the authors are aware, the review of optimizing MSW quality by the different drying methods has not been conducted yet. Therefore, this study highlighted the drying methods for optimization of MSW quality (excluding the other drying methods for drying solid wastes such as sludge and sewage sludge) to be effectively applied, based on the local conditions, available energy sources and affordable technologies.

\section{Methodology}

The data related to drying methods for optimization of MSW quality in this review study were collated from the published research papers and academic articles. The study summarized and highlighted the different MSW drying methods, drying parameters and changes of MSW quality before and after drying. Statistical analysis was performed to make a comparative analysis of the different drying methods regarding the reduction of moisture, weight and volume of MSW against the drying temperature and drying time. Based on the statistical analysis, the effect of moisture reduction on weight reduction and increase in heating value of MSW was also evaluated.

\subsection{Drying Methods}

Dryers use external heat sources or internal energy by organic waste decomposition [27, 29]. The dryers have been used for environmental engineering applications such as RDF drying, sludge dewatering [27] and MSW drying for fuel and reduced disposal at landfills [24, 33, 34, 45, 46]. The most common drying methods recently used around the world for optimization of MSW quality are as follows:

(a) Biodrying

(b) Biostabilization

(c) Solar Drying

(d) Thermal Drying

\subsubsection{Biodrying}

Biodrying is a treatment that uses natural and forced aeration along with the heat generated by natural aerobic bioconversion of some organic matter to dry the waste [50]. The main principle of biodrying process utilizes internal energy by organic waste decomposition [29]. Commonly, the involved microorganisms for the breakdown of the organic matters during biodrying process include bacteria, fungi, actinomycetes and celluloses degraders. The addition of inoculating materials at different time also exhibits various effects on the degradation rate of total organics and the performance of water removal and water content reduction [49]. Biodrying technology that removes water by microbial activities is a good potential for pretreatment of organic wastes with high water concentration [4, 47, 51].

Since it is an economic and environmentally friendly method [29], biodrying has been gaining attraction in Europe including 
Italy, Germany, United Kingdom, Spain, Poland, Greece, Romania [24, 32, 37, 39, 41, 42, 52] and in some parts of Asia including China, India and Malaysia [22, 29, 38, 43, 53]. Several studies $[4,22,27,29,32,34,37,38,40,43,47]$ have investigated biodrying process, mostly in a lab and pilot scale and partly in an industrial scale. The studies have concerned with solid wastes such as mixed or separated MSW, organic wastes and other wastes from municipal sectors and agricultural sectors. Biodrying technology can produce a high-quality bio-dried material within the lowest possible residence time (7-15 d) [29, 33, 39, 40, 41, 44]. The range of temperatures for a proper growth of the microorganisms during a biodrying process is between $40^{\circ} \mathrm{C}$ and $70^{\circ} \mathrm{C}$ with a proper aeration system inside the reactor [42].

As a type of biodrying, the greenhouse dryer is operated by the action of solar-energy striking directly on the product inside it [54]. The drying process in a greenhouse results in two main effects: (a) the metabolic heat generation by natural aerobic bioconversion of the organic matter, called the process of biodrying $[27,37,50]$ and (b) solar energy stored as heat inside the greenhouse that increases the air temperature [50]. During the drying process, the temperature and relative humidity in the greenhouse are higher than in outdoor conditions, hence, resulting in a positive effect on microorganisms in waste by improving microbial growth and activity [50]. Some type of greenhouse drying might be similar to the type of solar drying, depending on the type of drying. However, green house drying is mostly run by the direct sun energy rather than by the heat supplied from solar collector. Colomer-Mendoza et al. [31] stated that, during their research studies, the greenhouse dryer provided the initial volume reduction of wastes by more than 50\% within 12-30 d depending on the months [31].

\subsubsection{Biostabilization}

Biostabilization involves the enhanced biological degradation of organic matter, which can reduce MSW weight and volume, and decrease the environmental pollutions, such as leachate and landfill gas [46]. The microbial metabolism of the biostabilization is similar to that of biodrying. The main differences concern the preparation of materials to be processed, management criteria, process duration, emission factors and energy balance [42]. Time required for an effective biostabilization process is much longer than that of biodrying. Through innovative technologies for waste treatment, bio-stabilized materials can be used for agricultural purposes and stored safely in a landfill while bio-dried materials can be used as an energy source like fuel [37]. Despite the need of extra construction investment, operation and management (O\&M) costs, bio-stabilization can offer numerous economic advantages resulting from the combination of biostabilization and subsequent landfills, such as more efficient utilization of land space, leachate production and GHG emissions reduction, and post-closure costs savings [46].

\subsubsection{Solar drying}

The heat from the sun coupled with the wind has been used to dry food crops for preservation for several thousand years [55]. During the last decades, several developing countries have started to change their energy policies toward further reduction of petroleum import and to alter their energy use toward the utilization of renewable energies [25]. Accordingly, the availability of solar energy and the operational marketing and economy reasons offer a good opportunity for using solar drying all over the world [25]. Solar drying can benefit the environment due to its utilization of renewable energy source and exemption for GHG emission [16] despite the high capital investment cost.

In solar drying process, drying takes place in a modular solar dryer with forced convection, of which the design supports the heating and air circulation [30]. In solar drying of agricultural products, the moisture is removed by the solar heated air, having a temperature range of $50-60^{\circ} \mathrm{C}$ [56]. Solar dryers have been currently adopted in various type, size and design. Toshniwal and Karale [57] state that solar dryers can generally be classified, based on air movement mode, insulation exposure, air flow direction, dryer arrangement, solar contribution and type of the materials to be dried.

Numerous studies [6, 16, 25, 26, 30, 55-73] analyzed and reviewed various solar drying types, their drying periods and efficiencies related to drying of fruits, vegetables, agricultural and marine products, biomass and solid wastes, etc. Among them, Pawale et al. [73] proposed a potential design about hybrid MSW solar dryer with the solar absorber plate assembly and the electrical supplied heating coil as an external energy source. Shirinbakhsh and Amidpour [6] also designed a new large-scale Solar-Assisted Conveyer-Belt Dryer (SACBD) to dry biomass in large facilities. According to these scholars, the designed SACBD system consisted of a flat-plate solar air heater, photovoltaic (PV) panels, a circulating fan, a heat exchanger, a drying chamber, and a cyclone separator. The system was designed to dry 0.1 tonnes of biomass per hour (on the dry basis) in the climatic conditions of Tehran [6].

\subsubsection{Thermal drying}

The dewatering option is named thermal drying when an external auxiliary energy source allows the heating of the waste [24]. During thermal drying, a significant amount of thermal energy needs to be transferred to the wet solids to evaporate the water and to heat the solids and remaining water [65]. Yuan et al. [4] assert that although use of thermal drying enables a product with high solid content to be rapidly obtained, this technique is, in most cases, neither cost-effective nor environmentally friendly because a non-renewable energy resource is consumed. The approach of thermal drying has been fully developed for sewage sludge [24] but the applications of drying MSW are found to be emerging.

Bukhmirov et al. [74] conducted the research on the convective thermal drying process at 0.1 meters per second of hot air flow rates in an experimental scale. Bukhmirov et al. reported that about $100 \%$ of moisture reduction in MSW were achieved at drying temperature of $107-167^{\circ} \mathrm{C}$ during $160-260$ min. Lawanangkul [75] conducted the research study on the improvement of thermal efficiency of a gasifier with a new fuel drying system by waste heat from an internal gas engine. The fuel drying system was designed to improve the thermal efficiency of the gasifier by reducing the moisture content of MSW from 50\% to $20 \%$. Lawanangkul outlined that the improved gasifier design with the 
recovered waste heat could be commercially profitable and environmentally friendly since the utilized fuel was biomass.

When the drying oven is used for drying process, it causes the objects to dry out through evaporation, by using convection heating, in which the object is heated by air currents [76]. Gravity convection or forced air convection drying ovens could provide a greater degree of evenness, control of temperature, rapid drying capabilities [77]. Oven drying can yield efficient dehydration process and short drying times [78], with a maximum temperature of $250-350^{\circ} \mathrm{C}$ [77].

\subsection{Effect of Bulking Agents}

Bulking agents (BA) are carbon sources such as wood chips, leaves and yard trimmings, corn cobs, stalks and straw [79]. They can promote pore spaces allowing for more oxygen through the pile [79]. To achieve efficient drying of MSW, it is imperative to ensure high porosity within the waste matrix [33]. Several researchers $[4,33,80,81]$ have used BA to improve the efficiency of bio-drying process by adjusting the initial moisture content and free air space of waste which provides high porosity and easier transport of oxygen through the waste matrix.

\section{Comparison of Drying Methods}

Table 1 shows the reviewed drying methods, drying parameters and MSW properties before and after drying. Drying methods includes biodrying, biostabilization, thermal drying and solar drying. Different drying methods might have different drying efficiencies based on the types of drying, capacity of the reactors, size of materials to be dried, drying temperature, ventilation monitoring, turning effects, drying time, use of external heat sources, etc.

The moisture reduction, weight reduction, volume reduction and heating value increase of MSW after drying process were estimated as follows:

$$
\text { Moisture reduction }(\%)=
$$

Initial moistrue content - Final moisture content Initial moisture content

Weight reduction $(\%)=$

$\frac{\text { Initial weight }- \text { Final weight }}{\text { Initial weight }} \times 100$

Volume reduction $(\%)=$

$\frac{\text { Initial volume }- \text { Final volume }}{\text { Initial volume }} \times 100$

$$
\text { Heating value increase }(\%)=
$$

$$
\frac{\text { Final heating value }- \text { Initial heating value }}{\text { Initial heating value }} \times 100
$$

\subsection{Comparison of Applied Drying Methods around the World}

According to the research studies, it is observed that various drying methods for optimization of MSW have been adopted around the world. Table 2 presents the comparison of the applied drying methods in the world. Among them, most developed and developing countries have focused significantly on biodrying as a major drying method. This drying method is most suitable for the treatment of the wastes with high moisture contents within a proper drying period. The study [24] pointed out the existing and planned biodrying plants in Europe, majorly in Germany, Italy, Spain and UK had about 20 plants, ranging a capacity of 40,000-360,000 tons per year. Biostabilization and thermal drying have also applied in an industrial scale. Meanwhile, the research and development related to solar drying have been conducted in a lab and pilot scale for drying of food wastes only in developing countries (Jordan and Egypt). However, this drying method could be emerging due to an advancement of technologies. Hence, the countries with high solar radiation could take advantages of the solar energy resource for MSW drying to gain waste fuel and reduce the volume and moisture content of bulk wastes for easier transportation and safer disposal at landfills.

\subsection{Comparison of Drying Methods Based on Drying Temperature and Drying Time}

Fig. 2 shows the comparison of drying methods based on the drying temperature and drying time. Regarding the research studies as described in Table 1 above, the drying temperature of thermal drying process could range approximately from $60^{\circ} \mathrm{C}$ to $200^{\circ} \mathrm{C}$. This drying method could provide faster drying efficiency in a shorter time as compared to other drying methods. With this drying method, $100 \%$ moisture reduction could be achieved, allowing $87 \%$ weight reduction and $70 \%$ volume reduction during the drying period of 6-10 h [74]. Among the different drying methods, biostabilization process takes the longest period, but it could reduce the weight of MSW by $85 \%$ in $100 \mathrm{~d}$, as stated by $\mathrm{He}$ et al. [46]. The drying temperature of the different drying

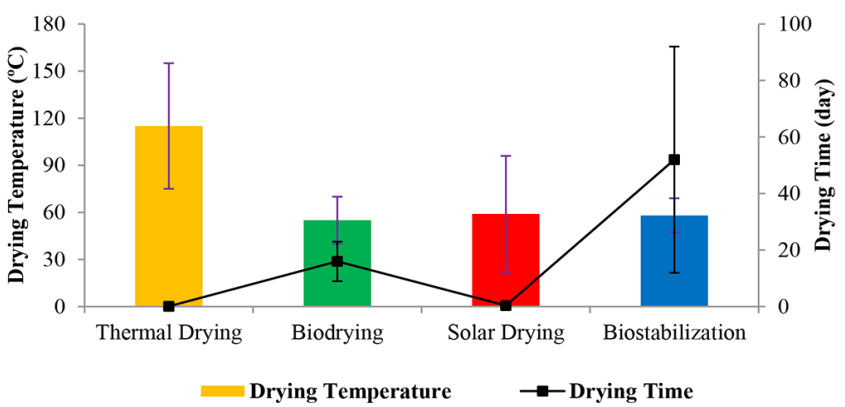

Fig. 2. Comparison of drying methods based on drying temperature and drying time. 


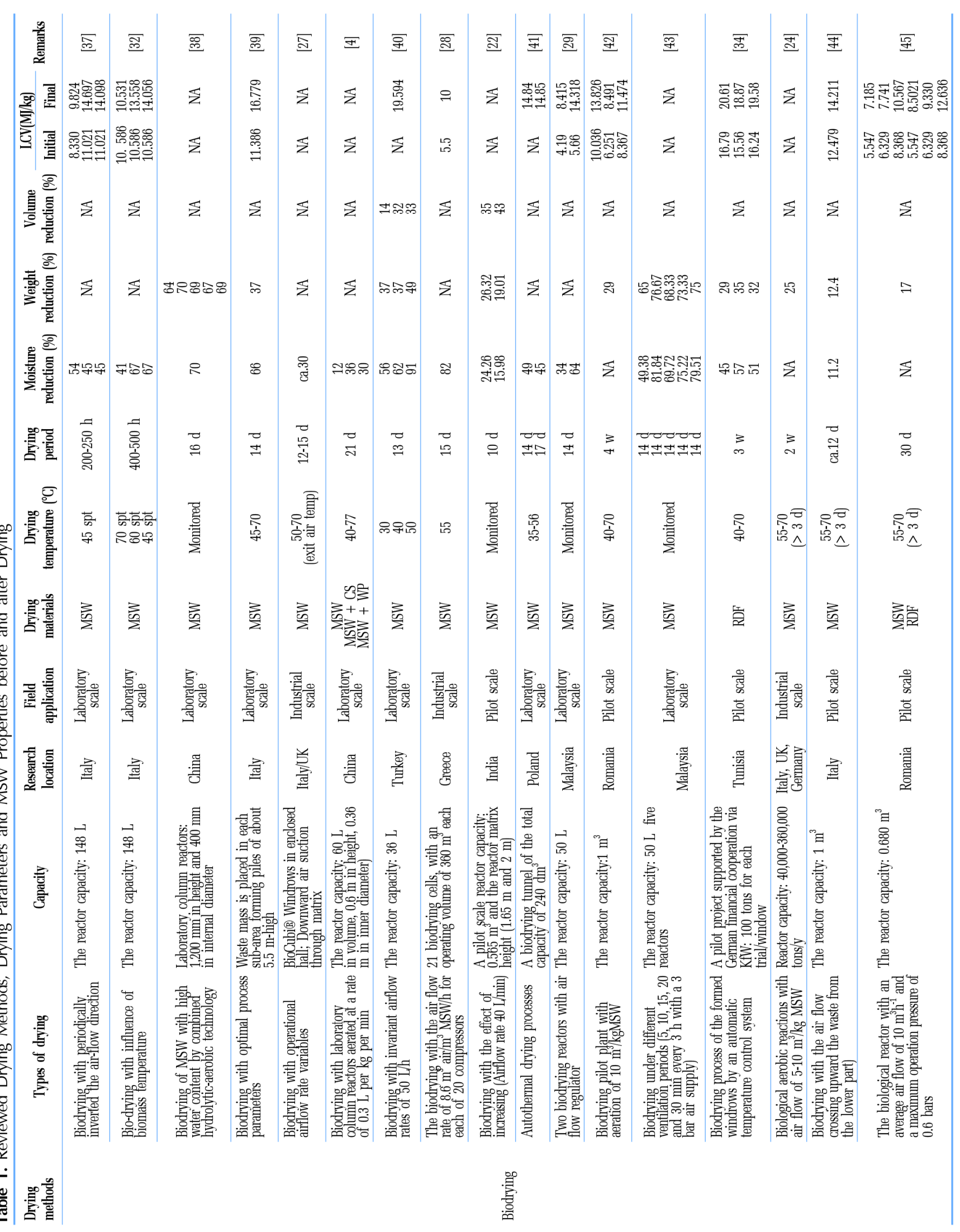




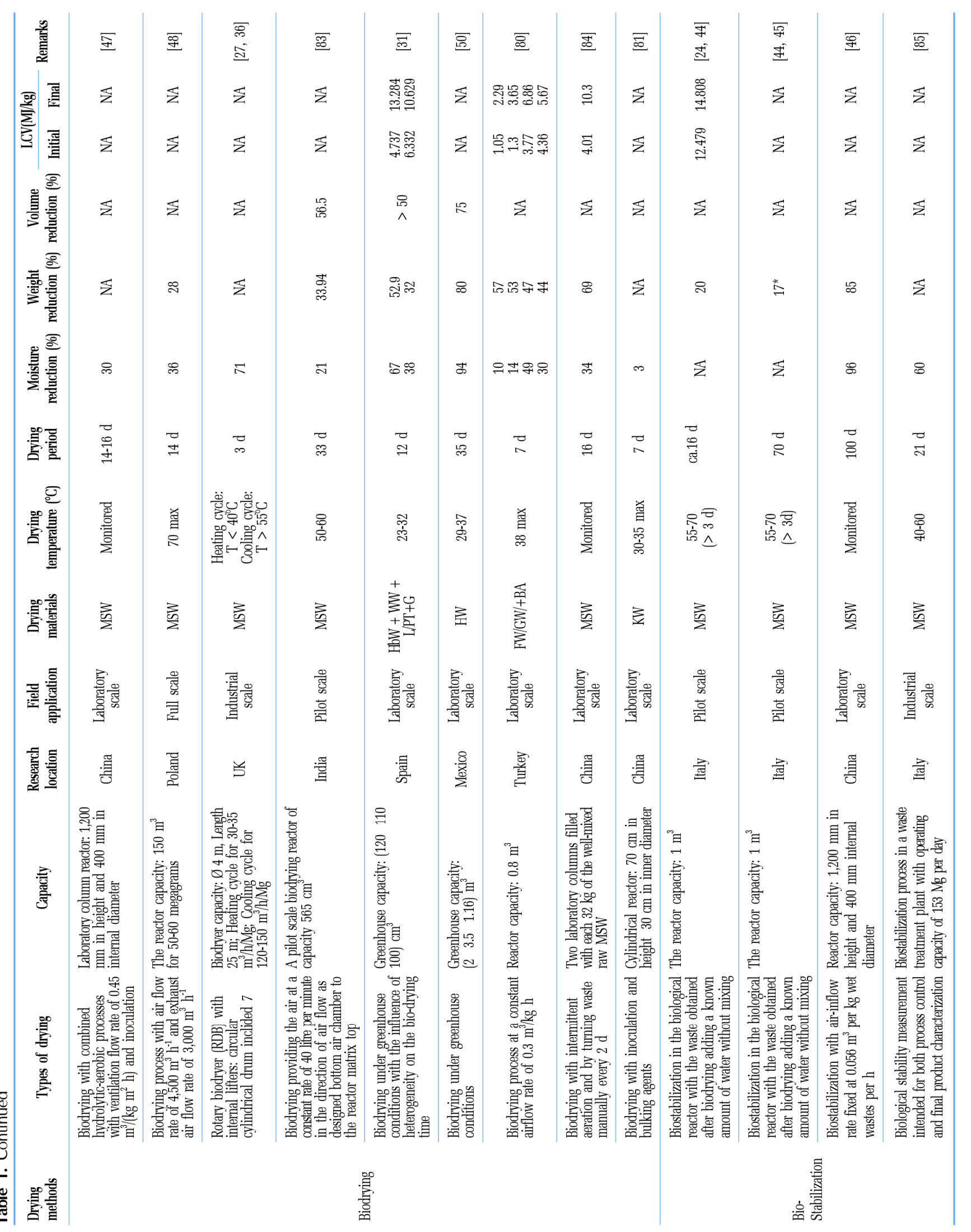




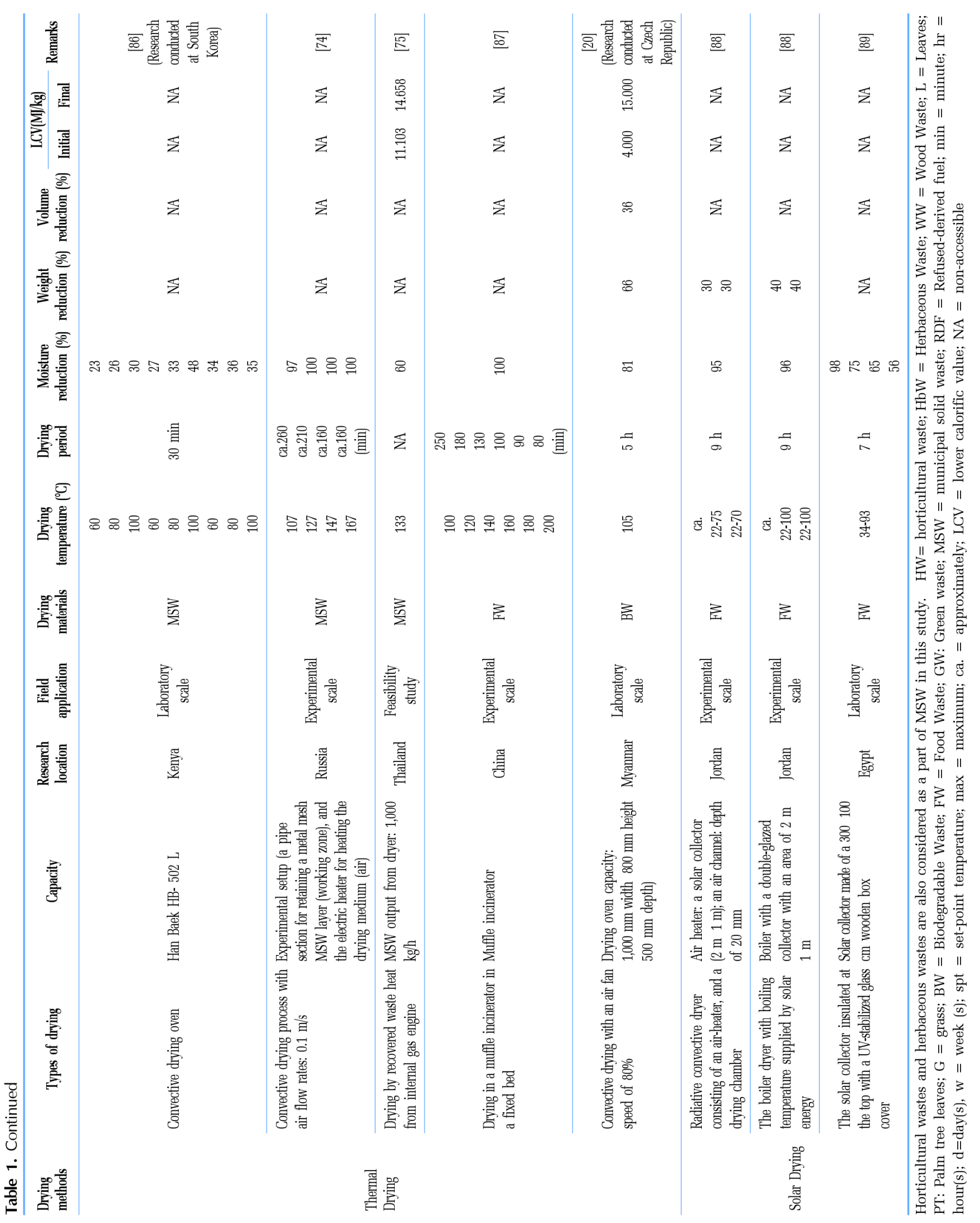


Table 2. Comparison of Applied Drying Methods around the World [4, 20, 22, 24, 27-29, 31, 32, 34, 36-50, 74, 75, 80-90]

\begin{tabular}{|c|c|c|c|c|c|c|c|}
\hline \multirow{2}{*}{$\begin{array}{l}\text { Types of drying } \\
\text { methods }\end{array}$} & \multirow{2}{*}{$\begin{array}{l}\text { Number of } \\
\text { research papers }\end{array}$} & \multicolumn{3}{|c|}{ Types of field applications } & \multicolumn{2}{|c|}{ Country groups } & \multirow[b]{2}{*}{ Remarks } \\
\hline & & $\begin{array}{l}\text { Laboratory } \\
\text { scale }\end{array}$ & $\begin{array}{l}\text { Pilot } \\
\text { scale }\end{array}$ & $\begin{array}{l}\text { Industrial } \\
\text { scale }\end{array}$ & $\begin{array}{c}\text { Developed } \\
\text { countries }\end{array}$ & $\begin{array}{c}\text { Developing } \\
\text { countries }\end{array}$ & \\
\hline Biodrying & 28 & 17 & 7 & 4 & 13 & 15 & $\begin{array}{l}\text { [a] Values were based on the number } \\
\text { of research papers that were collected } \\
\text { by the year } 2018 \text {. }\end{array}$ \\
\hline Biostabilization & 5 & 1 & 2 & 2 & 4 & 1 & $\begin{array}{l}\text { countries were categeorized based on } \\
\text { the World Bank } 2012 \text { Report. }\end{array}$ \\
\hline Thermal drying & 5 & 2 & 3 & * & * & $5^{*}$ & $\begin{array}{l}\text { study were assumed as pilot scale } \\
\text { while full scale was assumed as } \\
\text { industrial scale. }\end{array}$ \\
\hline Solar drying & 2 & 1 & 1 & - & - & 2 & $\begin{array}{l}\text { * Although thermal drying is being } \\
\text { applied in an industrial scale, the } \\
\text { available research papers were currently } \\
\text { very few. }\end{array}$ \\
\hline
\end{tabular}

methods accounted for $59 \pm 37^{\circ} \mathrm{C}$ for solar drying, $115 \pm 40{ }^{\circ} \mathrm{C}$ for thermal drying, $55 \pm 15^{\circ} \mathrm{C}$ for biodrying and $58 \pm 11^{\circ} \mathrm{C}$ for biostabilization. Meanwhile, the drying time of these methods was $0.38 \pm 0.04 \mathrm{~d}$ for solar drying, $0.11 \pm 0.06 \mathrm{~d}$ for thermal drying, $16 \pm 7 \mathrm{~d}$ for biodrying and $52 \pm 40 \mathrm{~d}$ for biostabilization.

\subsection{Comparison of Drying Methods based on Final Drying Time against the Reduction of Moisture, Weight and Volume of MSW}

Fig. 3(a), Fig. 3(b) and Fig. 3(c) present the comparison of drying
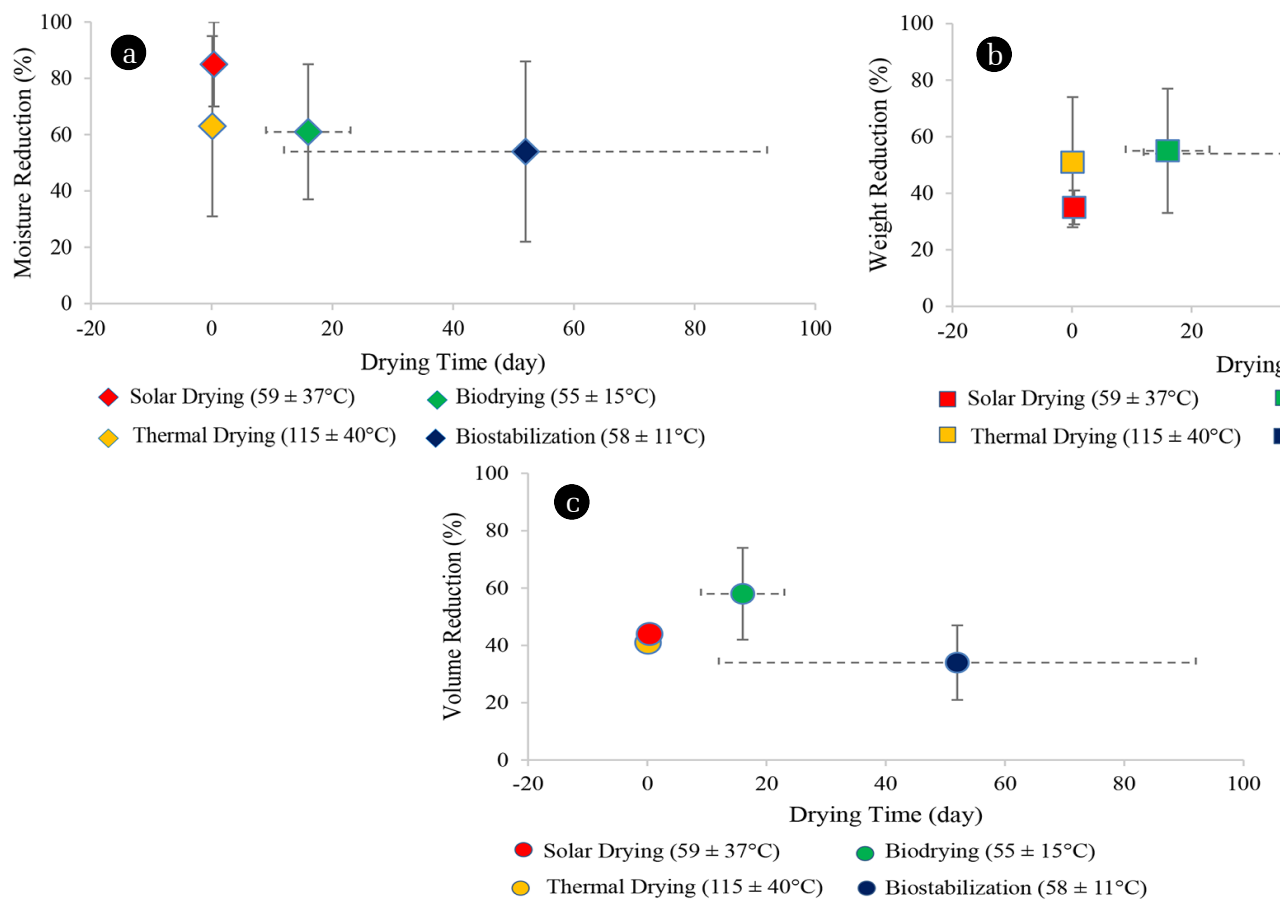

Fig. 3. (a) Final drying time versus moisture reduction, (b) final drying time versus weight reduction and (c) final drying time versus volume reduction for different drying methods. methods, based on the final drying time against the reduction of moisture, weight and volume of MSW. Regarding the research studies as shown in Table 1 above, it was observed that the reduction of moisture, weight and volume of MSW would depend strongly on the types of drying, drying temperatures, size and type of materials, proper ventilation, turning effects, addition of bulking agents, drying period, etc. The moisture reduction of MSW accounted for $85 \pm 17 \%$ by solar drying, $63 \pm 32 \%$ by thermal drying, $61 \pm 24 \%$ by biodrying and $54 \pm 32 \%$ by bio-stabilization. Meanwhile, the weight reduction of MSW accounted for $35 \pm 6 \%$ by solar drying, $51 \pm 23 \%$ by thermal

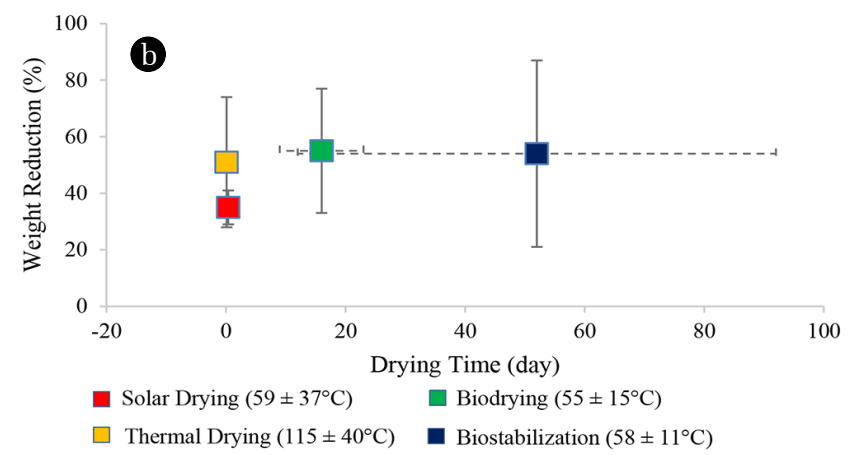


drying, $54 \pm 22 \%$ by biodrying and $55 \pm 33 \%$ by bio-stabilization Likewise, the volume reduction of MSW accounted for $44 \pm$ $1 \%$ by solar drying, $41 \pm 3 \%$ by thermal drying, $58 \pm 16 \%$ by biodrying and $34 \pm 13 \%$ by biostabilization. The drying time of these methods were $0.38 \pm 0.04 \mathrm{~d}$ for solar drying, $0.11 \pm$ $0.06 \mathrm{~d}$ for thermal drying, $16 \pm 7 \mathrm{~d}$ for bio-drying and $52 \pm$ $40 \mathrm{~d}$ for biostabilization.

\subsection{Effect of Moisture Reduction on Weight Reduction and Heating Value Increase}

To analyze the effect of the moisture reduction on the weight reduction and heating value increase of the MSW in a consistent way, the authors considered the samples be the mixed MSW alone, excluding the food wastes, biodegradable wastes, kitchen wastes, RDF, etc. Besides, since there were insufficient data or lack of data about the moisture reduction, weight reduction and heating value increase of MSW in most research studies related to solar drying, thermal drying and biostabilization, it is not currently possible to perform a statistical analysis. However, as these required data were sufficient in biodrying process, statistical data analysis was performed on the variables related to the moisture reduction of MSW for this drying method.

To examine the strength and direction of linear relationship between the variables, Pearson correlation was calculated for each pair of the variables (Table 3). The significance of correlation coefficient was determined by comparison of the $p$-value to significance level 0.05 . Correlation was significant ( $p$-value was below the significance level of 0.05 ) in the following pairs of variables: moisture reduction and weight reduction; moisture reduction and heating value increase.

The effect of moisture reduction on weight reduction and heating value increase of MSW from biodrying process in developed

Table 3. Values of Correlation Coefficient, Sample Size and p-values of Different Variables Related to Moisture Reduction for Biodrying Process

\begin{tabular}{lccccc}
\hline & \multicolumn{2}{l}{ Description } & \multicolumn{2}{c}{ Developed countries Developing countries Developed countries Developing countries } \\
\cline { 2 - 6 } & Correlation coefficient & 0.79 & 0.92 & Heating value increase \\
\hline \multirow{2}{*}{$\begin{array}{l}\text { Moisture } \\
\text { reduction }\end{array}$} & Sample size & 20 & 5 & 0.71 & 0.80 \\
& $p$-value & 0.00004 & 0.02550 & 0.0139 & 8 \\
\hline
\end{tabular}
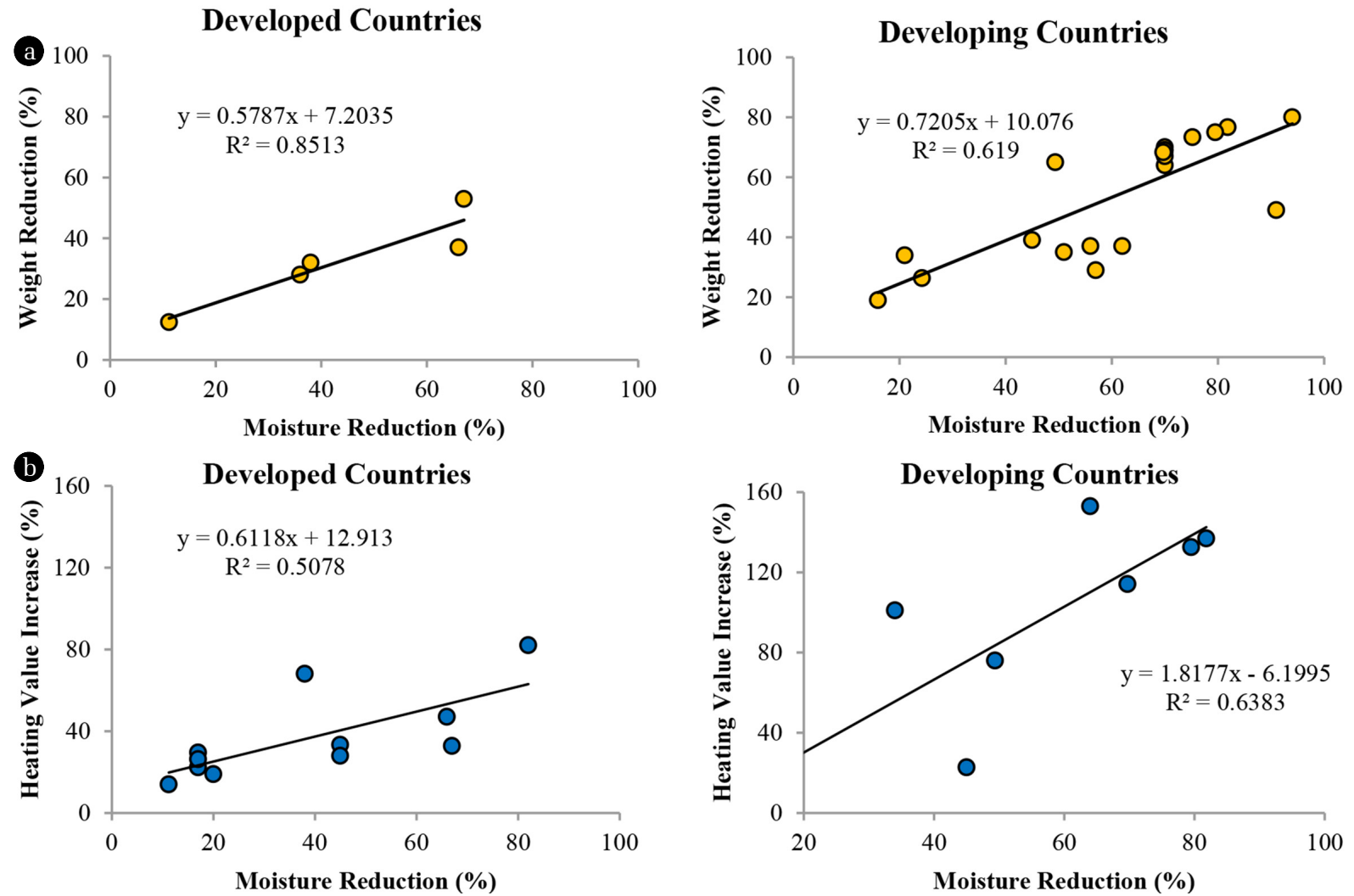

Fig. 4. (a) Moisture reduction versus weight reduction and (b) moisture reduction versus heating value increase of MSW from biodrying process in developed countries and developing countries. 
and developing countries is shown in Fig. 4(a) and Fig. 4(b), respectively. Generally, weight reduction and heating value increase of MSW could vary accordingly with moisture reduction. The higher moisture reduction from the bulk MSW wastes, especially in developing countries could supply higher weight reduction and higher heating value increase of the MSW. It was observed that $50 \%$ moisture reduction from the mixed MSW might provide approximately $35 \%$ and $45 \%$ weight reduction, and $45 \%$ and $85 \%$ heating value increase in developed and developing countries, respectively (Fig. 4(a) and Fig. 4(b)). It is due to that the effect of moisture reduction on weight reduction and heating value increase depends strongly on the types and composition of MSW in developed and developing countries. Generally, developed countries have higher combustible fraction and lower moisture content of the MSW. Meanwhile, developing countries have higher organic fraction and higher moisture content of the MSW. Therefore, the effect of moisture reduction on the weight reduction and heating value increase of the MSW in developed countries is comparatively lower than that of developing countries.

\section{Comparison between Benefits and Drawbacks of Drying Methods for MSW Drying}

Regarding the different nature of drying methods related to MSW drying, the comparison between the benefits and drawbacks is briefly presented in Table 4 . Comparisons were made based on drying period, drying temperture, reduction of moisture, volume, weight, odor and leachate, improvement of fuel quality, requirement of auxiliary energy, possibility of material recovery for recyclables, acceptability for waste storage, cost of dryers and purpose of usage of dried materials such as fuel for waste-to-energy, disposal at landfill and agriculture use.

Despite the advantages of biodrying method for the reduction of weight, volume and moisture of MSW, it might be a kind of costly technologies for the developing countries. However, biodrying under greenhouse conditions are quite suitable for developing countries that have higher solar radiation since it is cheap and can be operated by local accessible technologies. Biodrying is most suitable for creating a renewable energy source from wastes and safer disposal at landfills. Like a biodrying process, biostabilization is also suitable for biostabilation of wastes to dispose safely at landfills. This method could offer several benefits including volume reduction of wastes, minimized landfill use and reduced environmental impacts. However, its drawbacks include longer periods of the stabilization process.

Solar drying is also most suitable for the countries that have enough solar radiation while thermal drying can be implemented by an external heat source or waste heat disposed from the power plants such as international combustion engines and gas turbines. The benefits of these methods have shorter drying periods. However, thermal drying may have higher operation and maintenance cost for large scale drying processes, if applied only by external heat sources, except waste heat.

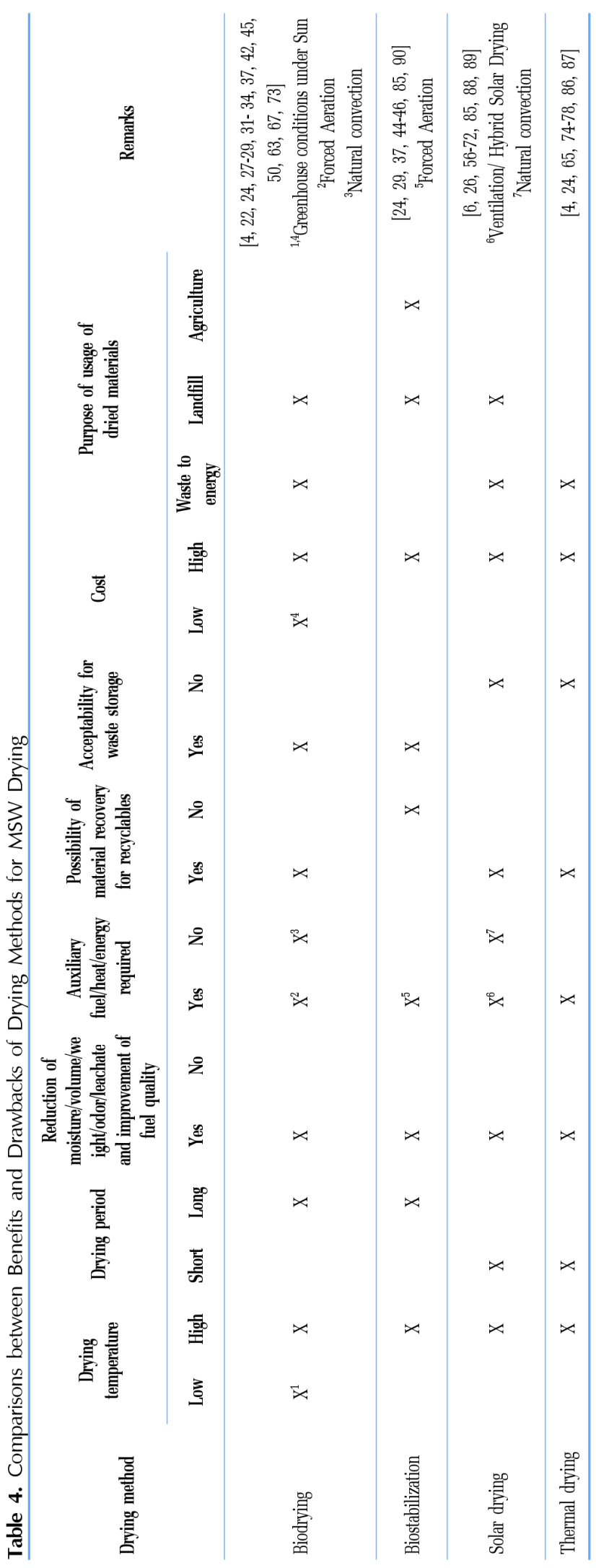




\section{Recommendations}

Nowadays, the energy-oriented conversion technologies are gaining attractions in the developed and developing countries to valorize wastes for a renewable energy source, reduce dependency on fossil fuel and keep safer disposal at landfills. Among them, biodrying, biostabilization, thermal drying and solar drying are the most common. The crucial factors for consideration of suitable dryers are materials to be handled, size of materials, feed rate, heat source, quality of dried product, construction cost, and operation and maintenance cost [75]. Among them, one of the most important factors in choosing a drying method is the cost for using a dryer [29]. However, the considerations for reduction of dryer cost should include economic and environmental benefits such as transportation cost, reduced disposal cost at landfill, recovered recyclable materials from MSW, waste fuel for energy production, GHG emission avoidance from dried wastes and reduction of environmental pollution.

The drying efficiency of different drying methods can be improved by mixing bulking agents into the wastes. Bulking agents could help adjust the initial moisture content of MSW and provide the high porosity in MSW for easier transport of air into the drying MSW materials. Likewise, drying of separated wastes such as wastes with a removal of glass or other inert wastes could also offer more benefits in faster drying efficiency and increase higher heating values of the separated wastes than drying of mixed wastes alone. One thing that should be careful about drying is that the dried waste materials should be carefully stored in the store room to avoid affecting dried materials from air humidity from the surrounding and of preventing dried materials from fire.

Moreover, the energy source for drying should be cheap and reliable. If it is derived from renewable energy sources and other waste heat sources, drying process will be more economical and environmentally friendly. Currently, most research experiments related to MSW drying have been well-developed to a considerable degree around the world. Likewise, drying technologies could significantly play a key role for approaching a sustainable waste management system to gain environmental and economic benefits in the future.

\section{Conclusions}

Nowadays, various drying methods for optimization of MSW quality have been adopted and applied in the developed countries and developing countries. Thermal drying and biodrying have been applied from laboratory and pilot scales to industrial scales. Meanwhile, the development of other drying methods is also emerging. With several environmental and economic benefits, drying of MSW could be a good potential of valorizing wastes for a renewable energy source, reduced dependency on fossil fuel, safer disposal at landfills and conservation of the environment in the future.

\section{Acknowledgments}

The study was funded by the Ministry of Education, Youth and
Sports of the Czech Republic and the project: CZ.02.1.01/0.0/0.0/ 16_019/0000753.

\section{References}

1. Hoornweg D, Bhada-Tata P. What a waste: A global review of solid waste management. Urban development series knowledge papers. 2012;15. p. 1-98.

2. Tchobanoglous G, Kreith F. Handbook of solid waste management. 2nd ed. New York: McGraw-Hill; 2002.

3. Wilson DC, Rodic L, Modak P, et al. Global waste management outlook. In: UN Environment; 8 September 2015; Nairobi.

4. Yuan J, Zhang D, Li Y, et al. Effects of adding bulking agents on biostabilization and drying of municipal solid waste. Waste Manage. 2017;62:52-60.

5. Alamia A, Ström H, Thunman H. Design of an integrated dryer and conveyor belt for woody biofuels. Biomass Bioenerg. 2015;77:92-109.

6. Shirinbakhsh M, Amidpour M. Design and optimization of solar-assisted conveyer-belt dryer for biomass. Energ. Equip. Syst. 2017:5:85-94.

7. Glawe U, Visvanathan C, Alamgir M. Solid waste management in least developed Asian countries - A comparative analysis. International Conference on Integrated Solid Waste Management in Southeast Asian Cities. 2005; p. 5-7.

8. Ngoc UN, Schnitzer H. Sustainable solutions for solid waste management in Southeast Asian countries. Waste Manage. 2009;29:1982-1995.

9. United Nations Environment Programme (UNEP). State of waste management in South East Asia, 2004 [Internet]. UNEP; c2017 [cited 27 March 2017]. Available from: http://www. asean.org/uploads/archive/files/UNEP.pdf.

10. Tun MM, Juchelková D. Assessment of solid waste generation and greenhouse gas emission potential in Yangon city, Myanmar. J. Mater. Cycles Waste Manage. 2018;20:1397-1408.

11. Lou XF, Nair J. The impact of landfilling and composting on greenhouse gas emissions - A review. Bioresour. Technol. 2009;100:3792-3798.

12. Clean Development Mechanism (CDM) Feasibility study. Final Report: Landfill Gas (LFG) Recovery and Utilization for Electric Power Generation, Mitsubishi UFJ Morgan Stanley Securities Co., Ltd. 2012.

13. El-Salam MM, Abu-Zuid GI. Impact of landfill leachate on the groundwater quality: A case study in Egypt. J. Adv. Res. 2015;6:579-586.

14. Nagarajan R, Thirumalaisamy S, Lakshumanan E. Impact of leachate on groundwater pollution due to non-engineered municipal solid waste landfill sites of erode city, Tamil Nadu, India. Iranian J. Environ. Health Sci. Eng. 2012;9:35.

15. Anilkumar A, Sukumaran D, Vincent SGT. Effect of municipal solid waste leachate on ground water quality of Thiruvananthapuram District, Kerala, India. Appl. Ecol. Environ. Sci. 2015;3:151-157.

16. Ferreira AG, Gonçalves LM, Maia CB. Solar drying of a solid waste from steel wire industry. Appl. Therm. Eng. 2014;73:104-110.

17. Minghua Z, Xiumin F, Rovetta A, et al. Municipal solid waste 
management in Pudong new area, China. Waste Manage. 2009;29:1227-1233.

18. Lupa CJ, Ricketts LJ, Sweetman A, Herbert BM. The use of commercial and industrial waste in energy recovery systems - A UK preliminary study. Waste Manage. 2011;31:1759-1764.

19. El Haggar S. Sustainable industrial design and waste management. 1st ed. Cradle-to-Cradle for Sustainable Development. Academic Press; 2007.

20. Tun M, Juchelková D, Raclavská H, Sassmanová V. Utilization of biodegradable wastes as a clean energy source in the developing countries: A case study in Myanmar. Energies 2018;11:3183.

21. RenoSam, Rambøll. The most efficient waste management system in Europe: Waste-to-energy in Denmark. published by RenoSam Vesterbrogade 24, 2. sal tv. DK-1620 Copenhagen V. 2016 [Internet]. RenoSam and Rambøll; c2017 [citied 14 March 2017]. Available from: https://stateofgreen.com/files/ download/275.

22. Tom AP, Haridas A, Pawels R. Biodrying process efficiency: Significance of reactor matrix height. Procedia Technol. 2016;25:130-137.

23. Perazzini H, Freire FB, Freire FB, Freire JT. Thermal treatment of solid wastes using drying technologies: A review. Dry. Technol. 2016;34:39-52.

24. Ragazzi M, Rada EC, Panaitescu V, Apostol T. Municipal solid waste pre-treatment: A comparison between two dewatering options. WIT Trans. Ecol. Environ. 2007;102:943-949.

25. Hii CL, Jangam SV, Ong SP, Mujumdar AS. Solar drying: Fundamentals, applications and innovations. Singapore: TPR Group Publication; 2012.

26. Ferreira AG, Gonçalves LM, Maia CB. Experimental analysis of industrial solid waste solar drying. 2013.

27. Velis CA, Longhurst PJ, Drew GH, Smith R, Pollard SJ. Biodrying for mechanical-biological treatment of wastes: A review of process science and engineering. Bioresour. Technol. 2009;100:2747-2761.

28. Evangelou A, Gerassimidou S, Mavrakis N, Komilis D. Monitoring the performances of a real scale municipal solid waste composting and a biodrying facility using respiration activity indices. Environ. Monit. Assess. 2016;188:302.

29. Ab Jalil NA, Basri H, Ahmad Basri NE, Abushammala MFM. The potential of biodrying as pre-treatment for municipal solid waste in Malaysia. J. Adv. Rev. Sci. Res. 2015;7:1-13.

30. Yoo JY, Kim HJ, Woo EJ, Park CJ. On solar energy utilization for drying technology. Int. J. Environ. Sci. Dev. 2017;8:305-311.

31. Colomer-Mendoza FJ, Robles-Martinez F, Herrera-Prats L, Gallardo-Izquierdo A, Bovea MD. Biodrying as a biological process to diminish moisture in gardening and harvest wastes. Environ. Dev. Sustain. 2012;14:1013-1026.

32. Adani F, Baido D, Calcaterra E, Genevini P. The influence of biomass temperature on biostabilization-biodrying of municipal solid waste. Bioresour. Technol. 2002;83:173-179.

33. Mohammed M, Ozbay I, Karademir A, Isleyen M. Pre-treatment and utilization of food waste as energy source by bio-drying process. Energ. Procedia 2017;128:100-107.

34. Elnaas A, Belherazem A, Müller W, Nassour A, Nelles M. Biodrying for mechanical biological treatment of mixed municipal solid waste and potential for RDF production. In: 3RD International Conference on Sustainable Solid Waste
Management, Tinos, Greece. 2015.

35. Verma M, Loha C, Sinha AN, Chatterjee PK. Drying of biomass for utilising in co-firing with coal and its impact on environment - A review. Renew. Sust. Energ. Rev. 2017;71:732-741.

36. Hood P, Smith SR, Skourides I. A method and system for treating mixed municipal and selected commercial waste. International Publication Number: WO 2008/065452 A2, 5-06-08, World Intellectual Property Organization. 2008; p. 17.

37. Sugni M, Calcaterra E, Adani F. Biostabilization-biodrying of municipal solid waste by inverting air-flow. Bioresour. Technol. 2005;96:1331-1337.

38. Zhang D, Pinjing HE, Liming SHAO, Taifeng JIN, Jingyao HAN. Biodrying of municipal solid waste with high water content by combined hydrolytic-aerobic technology. J. Environ. Sci. 2008;20:1534-1540.

39. Tambone F, Scaglia B, Scotti S, Adani F. Effects of biodrying process on municipal solid waste properties. Bioresour. Technol. 2011;102:7443-7450.

40. Bilgin M, Tulun Ş. Biodrying for municipal solid waste: volume and weight reduction. Environ. Technol. 2015;36:1691-1697.

41. Zawadzka A, Krzystek L, Ledakowicz S. Autothermal biodrying of municipal solid waste with high moisture content. Chem. Pap. 2010;64:265-268.

42. Negoi RM, Ragazzi M, Apostol T, Rada EC, Marculescu C. Biodrying of Romanian municipal solid waste: An analysis of its viability. UPB Sci. Bull. Ser. C 2009;71:193-204.

43. Ab Jalil NA, Basri H, Ahmad Basri NE, Abushammala MFM. Biodrying of municipal solid waste under different ventilation periods. Environ. Eng. Res. 2016;21:145-151.

44. Rada EC, Ragazzi M, Panaitescu V, Apostol T. MSW bio-drying and bio-stabilization: An experimental comparison. In: Proceedings of the International Conference: Towards integrated urban solid waste management system; November 2005; Trient. p. 6-10.

45. Rada EC, Ragazzi M, Panaitescu V, Apostol T. Bio-drying or bio-stabilization process? UPB Sci. Bull. Ser. C: Electr. Eng. 2005;67:51-60.

46. He PJ, Shao ZH, Zhang DQ, Shao LM. Bio-stabilization of municipal solid waste prior to landfill: Environmental and economic assessment. III International Symposium MBT and MRF. Waste-to-Resources; 2009.

47. Zhang DQ, He PJ, Jin TF, Shao LM. Bio-drying of municipal solid waste with high water content by aeration procedures regulation and inoculation. Bioresour. Technol. 2008;99: 8796-8802.

48. Dębicka M, Żygadło M. Full-scale biodrying process of municipal solid waste. In: E3S Web of Conferences; Conferences; 24 May 2017; Kielce. p. 7.

49. Zhang DQ, He PJ, Yu LZ, Shao LM. Effect of inoculation time on the bio-drying performance of combined hydrolytic-aerobic process. Bioresour. Technol. 2009;100:1087-1093.

50. Robles-Martínez F, Silva-Rodríguez EM, Espinosa-Solares T, et al. Biodrying under greenhouse conditions as pretreatment for horticultural waste. J. Environ. Prot. 2012;3:298-303.

51. Choi HL, Richard TL, Ahn HK. Composting high moisture materials: Biodrying poultry manure in a sequentially fed reactor. Compost Sci. Util. 2001;9:303-311.

52. Debicka M, Zygadlo M, Latosinska J. Investigations of bio-dry- 
ing process of municipal solid waste. Ecol. Chem. Eng. A 2013;20:1461-1470.

53. Zhang D-Q, He P-J, Shao L-M. Potential gases emissions from the combustion of municipal solid waste by bio-drying. J. Hazard. Mater. 2009;168:1497-1503.

54. Tiwari A. A review on solar drying of agricultural produce. J. Food Process. Technol. 2016;7:326.

55. Solar Drying. Technical Brief. Practical Action. The Schumacher Centre, Bourton on Dunsmore, Rugby, Warwickshire, CV23 9QZ, United Kingdom, 2007.

56. Kumar M, Sansaniwal SK, Khatak P. Progress in solar dryers for drying various commodities. Renew. Sust. Energ. Rev. 2016;55:346-360.

57. Toshniwal U, Karale SR. A review paper on solar dryer. Int. J. Eng. Res. Applic. 2013;3:896-902.

58. Weiss W, Buchinger J. Solar drying. Training course within the scope of the project: Establishment of a production, sales and consulting infrastructure for solar thermal plants in Zimbabwe. Arbeitsgemeinschaft Erneuerbare Energie Institute for Sustainable Technologies: AEEIntec, Austria Development Corporation, Gleisdorf, Austria. 2015.

59. Leon MA, Kumar S, Bhattacharya SC. A comprehensive procedure for performance evaluation of solar food dryers. Renew. Sust. Energ. Rev. 2002;6:367-393.

60. Khalifa AJN, Al-Dabagh AM, Al-Mehemdi WM. An experimental study of vegetable solar drying systems with and without auxiliary heat. ISRN Renew. Energ. 2012;2012:article ID 789324.

61. Fudholi A, Sopian K, Ruslan MH, Alghoul MA, Sulaiman MY. Review of solar dryers for agricultural and marine products. Renew. Sust. Energ. Rev. 2012;14:1-30.

62. Phadke PC, Walke PV, Kriplan VM. A review on indirect solar dryers. ARPN J. Eng. Appl. Sci. 2015;10:3360-3371.

63. Bentayeb F, Bekkioui N, Zeghmati B. Modelling and simulation of a wood solar dryer in a Moroccan climate. Renew. Energ. 2008;33:501-506.

64. Dhanushkodi S, Wilson VH, Sudhakar K. Simulation of solar biomass hybrid dryer for drying cashew kernel. Adv. Appl. Sci. Res. 2016;6:148-154.

65. Water Environment Federation. Residuals and Biosolids Committee Bioenergy Technology Subcommittee. Fact Sheet: Drying of wastewater solids. January 2014 [Internet]. Water Environment Federation; c2018 [cited 16 February 2018]. Available from:http://www.wrrfdata.org/NBP/DryerFS/Drying of_Wastewater_Solids_Fact_Sheet_January2014.pdf.

66. Anlagenbau GmbH. Solare Trocknungstechnik. Solar sewage sludge drying: Drying Principles [Internet]. Anlagenbau $\mathrm{GmbH}$; c2018 [cited 16 February 2018]. Available from: http://www.wendewolf.com/klssystem.php?lang=en.

67. Waste and Sludge Drying, 2013 [Internet]. Sunfish Solar Energy Limited; c2018 [cited 16, February 2018]. Available from: http://www.sunfishsolar.com/heatingdrying/.

68. Prakash O, Kumar A. Solar greenhouse drying: A review. Renew. Sust. Energ. Rev. 2014;29:905-910.

69. Fadhel MI, Sopian K, Daud WRW, Alghoul MA. Review on advanced of solar assisted chemical heat pump dryer for agriculture produce. Renew. Sust. Energ. Rev. 2011;15:1152-1168.

70. VijayaVenkataRaman S, Iniyan S, Goic R. A review of solar drying technologies. Renew. Sust. Energ. Rev. 2012;16:2652-2670.

71. El-Sebaii AA, Shalaby SM. Solar drying of agricultural products: A review. Renew. Sust. Energ. Rev. 2012;16:37-43.

72. Mattfeld B. Solar sludge drying system helps reduce hauling costs [Internet]. c2018 [cited 28, January 2018]. Available from: http://www.waterworld.com/articles/print/volume-28/issue-2/ editorial-features/solar-sludge-drying-system-helps-reducehauling-costs.html.

73. Pawale PD, Dharmarao SS, Pawar MS. Solar assisted dryer for municipal solid waste. Int. J. Innov. Eng. Res. Technol. 2015;2:1471963.

74. Bukhmirov VV, Kolibaba OB, Gabitov RN. Experimental research of solid waste drying in the process of thermal processing. In: IOP Conference Series: Materials Science and Engineering; October 2015. p. 012006.

75. Lawanangkul C. Municipal solid waste dryer by using waste heat design [dissertation]. Beppu: Ritsumeikan Asia Pacific Univ.; 2013.

76. What is a drying oven? [Internet]. Kohl A; c2018 [cited 28, January 2018]. Available from: https://www.hunker.com/ 12003453/what-is-a-drying-oven.

77. Drying Ovens. The buyer's guide for laboratory equipment [Internet]. Labcompare; c2018 [cited 28, January 2018]. Available from: https://www.labcompare.com/General-LaboratoryEquipment/4-Drying-Ovens/.

78. Nunes CA, Ribeiro TI, Nunes J. Comparative analysis of dehydration methods for apple fruit. Revista de Ciências Agrárias 2015;38:282-290.

79. Trent J. Food waste composting. Technical aspects and regulatory requirements. In: ISOSWO/APWA 2015 Spring Conference; 2015.

80. Mohammed M, Ozbay I, Durmusoglu E. Bio-drying of green waste with high moisture content. Process Saf. Environ. Prot. 2017;111:420-427.

81. Song X, Ma J, Gao J, et al. Optimization of bio-drying of kitchen waste: Inoculation, initial moisture content and bulking agents. J. Mater. Cycle. Waste Manage. 2017;19;496-504.

82. Yuan J, Li Y, Zhang H, et al. Effects of adding bulking agents on the biodrying of kitchen waste and the odor emissions produced. J. Environ. Sci. 2018;67:344-355.

83. Tom A P, Pawels R, Haridas A. Biodrying process: A sustainable technology for treatment of municipal solid waste with high moisture content. Waste Manage. 2016;49:64-72.

84. Shao LM, Ma ZH, Zhang H, Zhang DQ, He PJ. Bio-drying and size sorting of municipal solid waste with high water content for improving energy recovery. Waste Manage. 2010; 30:1165-1170.

85. Adani F, Tambone F, Gotti A. Biostabilization of municipal solid waste. Waste Manage. 2004;24:775-783.

86. Nzioka AM, Hwang HU, Kim MG, Troshin AG, CaoZheng Y, Kim YJ. Experimental investigation of drying process for mixed municipal solid waste: Case study of wastes generated in Nairobi, Kenya. Int. J. Adv. Agric. Environ. Eng. 2016;3.

87. Zhang Y, Chen M, Meng A, Li Q, Chen Y. Experimental study on drying of typical MSW under incinerator-like conditions. Sci. China Ser. E: Technol. Sci. 2007;50:636-643.

88. Nijmeh MN, Ragab AS, Emeish MS, Jubran BA. Design and testing of solar dryers for processing food wastes. Appl. Therm. 
Eng. 1998;18:1337-1346.

89. Tony MA, Tayeb AM. The use of solar energy in a low-cost drying system for solid waste management: Concept, design and performance analysis. In: Eurasia Waste Management Symposium; 14-16 November 2011; Istanbul.
90. Ball AS, Shahsavari E, Aburto-Medina A, Kadali KK, Shaiban AA, Stewart RJ. Biostabilization of municipal solid waste fractions from an Advanced Waste Treatment plant. J. King Saud Univ. Sci. 2017;29:145-150. 